\title{
Disaster risk reduction education in Indonesia: challenges and recommendations for scaling up
}

\author{
Avianto Amri ${ }^{1,2}$, Deanne K. Bird ${ }^{1,2,3}$, Kevin Ronan ${ }^{2,4}$, Katharine Haynes ${ }^{1,2}$, and Briony Towers ${ }^{2,5}$ \\ ${ }^{1}$ Risk Frontiers, Macquarie University, Sydney 2109, Australia \\ ${ }^{2}$ Bushfire and Natural Hazard Cooperative Research Centre, East Melbourne 3002, Australia \\ ${ }^{3}$ Institute of Life and Environmental Sciences, University of Iceland, 101 Reykjavik, Iceland \\ ${ }^{4}$ School of Human, Health and Social Sciences, Central Queensland University, North Rockhampton 4702, Australia \\ ${ }^{5}$ Geospatial and Mathematical Sciences, RMIT, Melbourne 3001, Australia \\ Correspondence to: Avianto Amri (avianto.amri@gmail.com)
}

Received: 22 December 2015 - Discussion started: 2 February 2016

Revised: 8 February 2017 - Accepted: 7 March 2017 - Published: 24 April 2017

\begin{abstract}
This article investigates the implementation of disaster risk reduction education for children in Indonesia. In the last decade, education programmes related to this subject have been promoted as capable of reducing disaster losses and increasing resilience, based on several studies that have identified positive outcomes. Therefore, it is critical to evaluate and address any potential challenges that might impede their success. The article uses a case study in Jakarta, a rapidly growing megacity that is highly prone to disasters and natural hazards, especially floods and fires, to explore the scaling up and sustainability of disaster risk reduction in Indonesian schools. Based on previous studies, a new approach was developed for evaluating the implementation of education programmes related to these subjects. This study captured the perspectives of children, school personnel, and non-governmental organisations on the challenges of scaling up the implementation of disaster risk reduction education in schools. The study revealed seven key issues and suggests several policy recommendations to move forward. These key issues may also be apparent in many other developing and developed countries, and the suggested recommendations may well be applicable beyond Indonesia.
\end{abstract}

\section{Introduction}

Children, defined by the United Nations (1989) as anyone below the age of 18 years, make up nearly one-third of the world's population (UNICEF, 2014). This represents a sig- nificant increase: just 20 years ago, children made up less than a quarter of the world's population (UNICEF, 1996). Children are considered one of the most at-risk groups in a disaster. WHO (2011) estimates that $30-50 \%$ of fatalities arising from natural hazard events are children. Children are more likely to be injured, have less access critical humanitarian assistance such as food and health care, and are exposed to other dangers, including separation from their families or caregivers (Peek, 2008). In the aftermath of a disaster, children can develop symptoms of post-traumatic stress disorder (PTSD), depression, anxiety, emotional distress, sleep disorders, somatic complaints, and behavioural problems (Masten et al., 2015; Newman et al., 2014; Norris et al., 2002).

Education is a key mechanism through which children can participate in disaster risk reduction (DRR) (Amri, 2015). There is growing anecdotal evidence that when children are supported by adults and are provided with sufficient knowledge and skills, they can protect themselves, save others from danger, and promote significant changes in their communities to adapt to climate change and reduce the risk of disasters (Back et al., 2009; Haynes and Tanner, 2015; Mitchell et al., 2008; Tanner, 2010; Webb and Ronan, 2014; Wisner, 2006). Recent empirical research has provided further support for children's agency in this realm (Haynes and Tanner, 2015; Towers, 2015).

Education has always been one of the priorities in the global commitment for DRR, as articulated in the Yokohama Strategy (United Nations, 1994), the Hyogo Framework for Action (HFA) 2005-2015 (UNISDR, 2005), and most re- 
cently the Sendai Framework for Disaster Risk Reduction 2015-2030 (UNISDR, 2015b). Substantial efforts have also been made to integrate DRR in the education sector (Ronan, 2014). In the 2013 Global Assessment Report, $72 \%$ of reporting countries specified that DRR had been integrated within their national education curriculum (Ronan, 2014).

Concurrently, there has been an increase in research examining DRR education in schools, including documenting positive outcomes. For example, children who have been exposed to a DRR education programme have better knowledge, reduced levels of hazard-related fears, and more accurate risk perceptions (Ronan et al., 2001, 2010; Ronan and Johnston, 2003).

Given the benefits that school-based DRR programmes can bring, it is critical to evaluate and address any potential challenges that might impede their success. It is therefore the aim of this study to identify challenges associated with implementing DRR education in schools, using Jakarta, Indonesia, as a case study example. The importance of this is twofold. Firstly, the government of Indonesia has made substantial gains in the integration of DRR into the education sector, including integrating DRR within school curricula and providing teachers with training on DRR education and school preparedness (BNPB, 2014; UNISDR, 2015a). However, international research has shown that there continues to be challenges with sustainability and scaling up of programmes (Johnson et al., 2014; Ronan, 2014). Alongside outcome effectiveness, sustainability and scaling up are the main issues related to DRR implementation within the school curricula internationally (Ronan, 2014). Despite this, there is a lack of published research assessing challenges associated with the implementation of DRR within schools in developing countries, particularly in the Indonesian context (Amri, 2015). It is therefore critical to identify the key challenges that Indonesia faces so that these can be considered when implementing DRR programmes within the school environment and thus ensure their success. Secondly, teachers, students, and households have low awareness and knowledge of DRR, particularly related to mitigation and preparedness strategies (BNPB, 2009; Desfandi, 2014; Sopaheluwakan et al., 2006). In these studies, access to DRR education materials, more preparedness planning at the household and community level, and support from relevant agencies were identified as key issues. In light of the above, this research focuses on the issues related to scaling up and sustainability components for DRR education.

The UNISDR (2009) defines DRR as a comprehensive and systematic approach to analysing and managing the causal factors of disasters, including through reduced exposure to hazards, lessened vulnerability of people and property, wise management of land and the environment, and improved preparedness for adverse events. This article captures the first phase of larger programmatic research and is focussed on several components of DRR (i.e. preparedness and response capacity). This approach was taken based on previous DRR education studies (e.g. Johnson et al., 2014; Ronan et al., 2010; Webb and Ronan, 2014) that focussed on preparedness and response. In addition, the Indonesian government has been emphasising these components with respect to DRR education (BNPB, 2012).

\subsection{Starting point of the study}

In order to identify the key challenges on the implementation of DRR education in Indonesia, this research builds on an initial study undertaken by Johnson et al. (2014, hereafter referred to as the Johnson study). Based on focus group discussions (FGDs) with New Zealand teachers, the Johnson study identified eight facilitators and eight deterrents that influence the use of DRR education material in "What's the Plan, Stan?", a national education programme developed by the New Zealand Ministry of Civil Defence (Table 1).

In addition to a focus on the views of school personnel, as in the Johnson study, this study captured the perspectives of children and non-governmental organisations (NGOs). Based on a literature review by Amri (2015), the role and views of other stakeholders are considered important, particularly NGO-based DRR professionals, as they are the main drivers for advocating and facilitating DRR in many developing countries, including Indonesia.

Thus, this study was designed to gather data that can help improve the implementation of DRR education within the Indonesian education sector. The following section provides a description of the case study location.

\subsection{Case study location: Jakarta, Indonesia}

Jakarta was selected as the study location (Fig. 1) due to a combination of rapid economic growth and urbanisation (Statistics Indonesia or BPS, 2015), a high level of urban poor living in high-risk areas (Baker, 2012), and a high prevalence of both geological and climate-related hazards with high vulnerability (Swiss Re, 2014).

In addition, as in many other developing countries, Jakarta has many active DRR programmes implemented by various government agencies and NGOs, including the United $\mathrm{Na}-$ tions (UN), World Bank, Red Cross, Save the Children, Child Fund, World Vision, Plan International, and Mercy Corps (Brown and Dodman, 2014; UNISDR, 2012; World Bank, 2014a).

From 2002 to 2014, four major floods occurred in Jakarta displacing close to 1 million people (BNPB, 2016). Major floods occur if heavy rainfall coincides with an extreme high tide (Sagala et al., 2013). As a result, children and schools are often significantly affected. For example, a post-disaster assessment of the 2013 flood reported that more than 70000 students from 251 primary schools in Jakarta could not access their school for 3 to 4 weeks due to flooding (Education Cluster, 2013). 
Table 1. Classroom and school-wide facilitators and deterrents to use of "What's the Plan, Stan?" (Johnson et al., 2014).

\begin{tabular}{ll}
\hline Facilitators & Deterrents \\
\hline School-wide use of the resource & Voluntary nature \\
Promotion of the resource by teachers & Lack of awareness of the DRR education resource \\
Direct engagement with local Ministry of Civil Defence and & $\begin{array}{l}\text { Perception that training is needed for its use } \\
\text { Emergency Management staff }\end{array}$ \\
Teacher's interest in the subject & Lack of school-wide use \\
Student's interest in the subject & Lack of relevancy when no disaster occurred \\
Good-quality design & Incompatibility with teaching methods \\
Recent disaster & Competing extracurricular topics \\
Teachers' training & Lack of direct engagement with local Civil Defence and Emer- \\
\hline
\end{tabular}

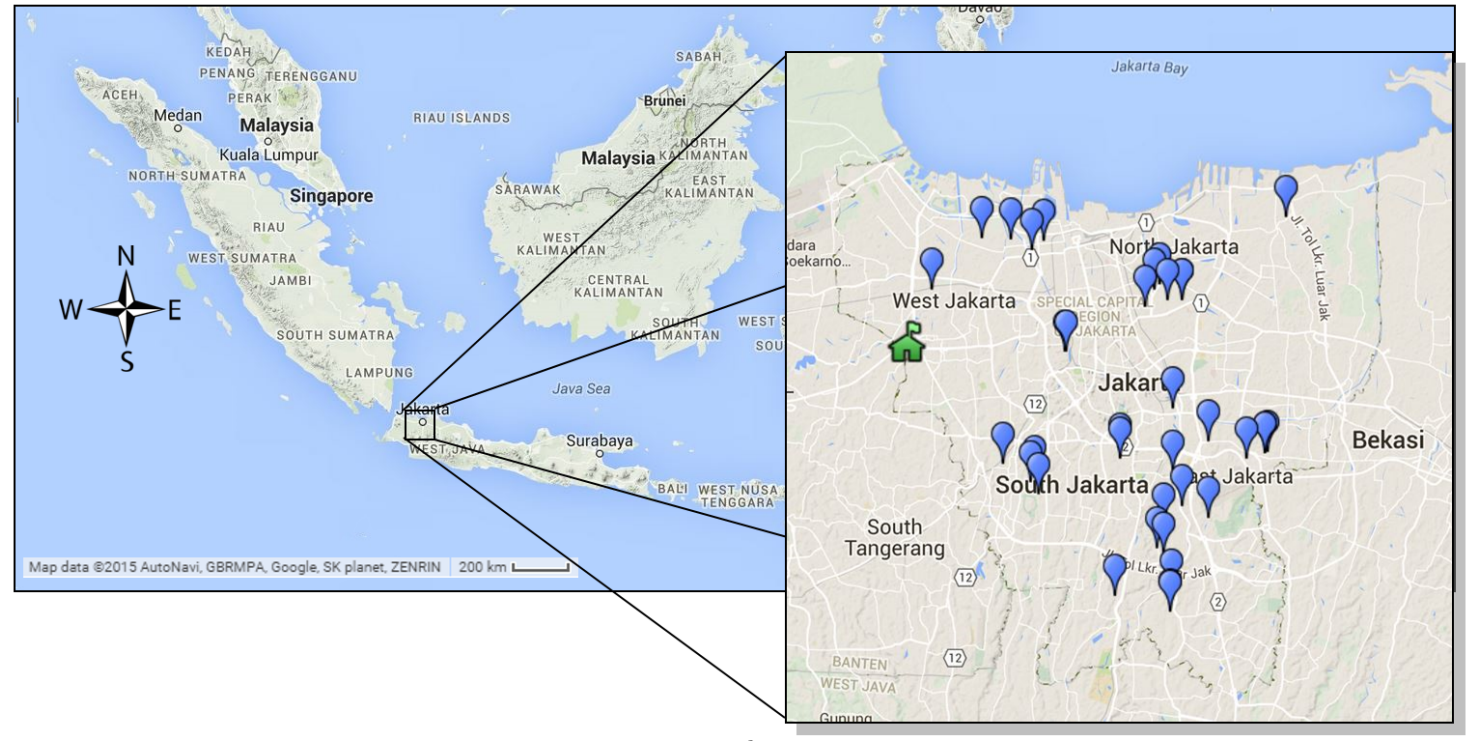

Figure 1. Map of Jakarta. Blue pins represent schools that participated in the school personnel survey. The green building symbol represents the school that participated in the student survey. (Image adapted from Scribble Maps @2015; map data from AutoNAVI, GBRMPA, Google, SK planet, and ZENRIN.)

Jakarta is also prone to fire hazards. From 2009 to 2013, fire incidences in Jakarta led to 141 deaths. Fire fatalities were 3 times greater than those caused by floods in the same period, which totalled 43 (BNPB, 2016; BPS, 2015).

\subsection{Basic education in Indonesia}

The Indonesian education system is the fourth largest in the world (World Bank, 2014b). There are more than 50 million students and almost 4 million teachers in more than 269000 schools spread over 17000 islands (Chang et al., 2013; Ministry of Education and Culture, 2012; World Bank, 2014b). More than $80 \%$ of schools are public (OECD/Asian Development Bank, 2015).

Since 2003, Indonesian schools have the authority to manage their operations independently with involvement from the local community as part of the school committee (Vernez et al., 2012). Schools also have the autonomy to develop the syllabus and learning materials and operationalise the curriculum based on the guidelines provided by the Curriculum Centre, a unit under the Ministry of National Education. In 2005 , the government of Indonesia enacted a new law that aims to improve the quality of teachers by providing mandatory certifications through courses and professional development (Chang et al., 2013).

Starting from 2009, the Indonesian government has piloted a DRR schools project originally named "disaster-prepared schools" (or Sekolah Siaga Bencana in Bahasa) but now called "disaster-safe schools" (or Sekolah/Madrasah Aman Bencana in Bahasa). According to a government report from 2013, there are more than 25000 schools that have implemented the disaster-safe schools programme supported by government agencies and/or NGOs (Ministry of Education and Culture, 2015). This report also indicates that the main intervention is focussed on non-structural measures, i.e. DRR education and the development of school disaster manage- 
ment plans. Schools participating in the programme are typically selected based on the recommendations of the local education offices and/or disaster management offices, based on their exposure and vulnerabilities to disaster hazards.

\section{Methodology}

This study used a multi-informant, mixed methods approach, focusing on three distinct groups: primary school personnel (i.e. teachers, school administrator, and school principals), DRR professionals within child-focussed NGOs working in Jakarta, and children. Firstly, a questionnaire was distributed to school personnel to assess the issues of implementing DRR education in schools based on their perspectives. Secondly, focus group discussions were conducted with DRR professionals to investigate the issues of scaling up and implementation, since these agencies have been advocating DRR education to be implemented nation-wide. Thirdly, children took part in the research through responding to a questionnaire that aimed to assess their knowledge and perspectives related to DRR. This third component of the methodology was undertaken to establish whether or not children should be included in DRR programmes, based on their current knowledge and desire to be involved.

Individual tools were developed for each stage of the research. These are available from the lead author on request. This study was approved by the Human Research Ethics Committee of Macquarie University (reference number 5201400846).

Using a critical realist approach, the overall analysis applied a thematic focus, stressing the pursuit of a better understanding of the underlying problems (Sayer, 1992). The authors were advancing and testing tools thought to be appropriate for Indonesia but also informed by previous international research, e.g. Johnson et al. (2014). The research was completed between late November 2014 and mid-January 2015. Each stage of the research is discussed in the following sections.

\subsection{School personnel questionnaire}

A questionnaire was developed for school personnel based on previous studies related to child-centred disaster risk reduction (CCDRR), including findings from previous studies that were adjusted for the Indonesian context (BNPB, 2013; GADRRRES and UNISDR, 2014; Haynes et al., 2009; Johnson et al., 2014; Save the Children, 2007a; Tanner, 2010; UNESCO and UNICEF, 2012). The questionnaire is available in the Supplement. The questions were framed and based around globally recognised frameworks such as the United Nations (1989), UNISDR (2005, 2014), and GADRRRES (2014). A similar approach was used in designing the children's questionnaire.
Five parameters that dealt specifically with the issue of DRR education were selected for analysis in this study: (1) child participation in DRR, (2) DRR-related activities in schools, (3) involvement of external stakeholders, (4) DRR education facilitators and deterrents, and (5) teachers' training in DRR.

Two questions related to facilitating and deterring factors of DRR education are central to this study. These factors included the eight deterrents and eight facilitators identified from the Johnson et al. (2014) study. Three deterrents and four facilitators were added in consideration of the Indonesian context (Table 2) to assess

- teachers' capacity for infusing DRR into the existing curriculum,

- the role of the community in influencing DRR education in schools,

- issues relating to the availability of resources (e.g. funding and dedicated personnel), and

- whether or not school personnel are aware of current policy.

The questionnaire was reviewed with several academic colleagues expert in this field.

The self-completed questionnaire was distributed at the end of a training session organised by the Jakarta Provincial Disaster Management Agency (BPBD) and the Consortium for Disaster Education (CDE). The training was a focussed session for personnel working in flood-prone primary schools in the Jakarta area to learn more about appropriate emergency response measures for their schools. While the training did not cover DRR education per se, the session was considered a good opportunity to target a large group of school personnel who not only worked at high-risk schools but would also have an increased awareness of the risks they faced and disaster-related terminologies and approaches, including DRR education.

All participants at the training session agreed to take part in the survey. An explanation of the nature of the research, including its purpose and ethics approval was provided. Participants completed the questionnaire in the same setting. However, they did not discuss their responses with each other.

A total of 44 members of staff from 39 flood-prone Jakarta primary schools completed the questionnaire (Fig. 1). They were from schools ranging in size from 107 to 500 students with an average of 273 students per school and included 7 school principals, 34 teachers, and 1 administrator. Two people did not state their positions. Participants included $22 \mathrm{fe}-$ males and 22 males, whose ages ranged from 22 to 59 years $(M=43.71, \mathrm{SD}=11.23)$. Descriptive statistics in Microsoft Excel were used to analyse the data. 
Table 2. Modified facilitators and deterrent for teachers to implement DRR education

\begin{tabular}{|c|c|c|}
\hline No. & Facilitators & Deterrents \\
\hline 1. & $\begin{array}{l}\text { Availability of useful "ready-to-go" and "child-friendly" teach- } \\
\text { ing resources }\end{array}$ & Lack of "ready-to-go" and "child-friendly" teaching resources \\
\hline 2. & $\begin{array}{l}\text { Promotion on the teaching resources by other teachers or edu- } \\
\text { cation personnel }\end{array}$ & $\begin{array}{l}\text { Lack of training in developing and/or delivering programmes of } \\
\text { this sort }\end{array}$ \\
\hline 3. & $\begin{array}{l}\text { Training available on how to develop and/or deliver such pro- } \\
\text { grammes for children }\end{array}$ & The topic is not relevant for the students \\
\hline 4. & The topic becomes a priority by the school management & The topic is not a priority by the school management \\
\hline 5. & $\begin{array}{l}\text { Topic is timely in relation to upcoming risk for local natural } \\
\text { hazards (e.g. bushfire, fire, cyclone, flooding seasons) }\end{array}$ & $\begin{array}{l}\text { Not compatible with my beliefs about what children should } \\
\text { learn in school }\end{array}$ \\
\hline 6. & Personal interest in the topic & Not enough space in the curriculum \\
\hline 7. & Student interest in the topic & $\begin{array}{l}\text { Weak coordination between schools, disaster management } \\
\text { agency, and local councils }\end{array}$ \\
\hline 9. & $\begin{array}{l}\text { Innovative methods for curriculum inclusion (e.g. combining } \\
\text { learning with school drills) }\end{array}$ & $\begin{array}{l}\text { Lack of knowledge in developing curriculum for disaster edu- } \\
\text { cation }\end{array}$ \\
\hline 10. & $\begin{array}{l}\text { Clear policies for school to deliver disaster risk reduction edu- } \\
\text { cation for children }\end{array}$ & Lack of interest from the community \\
\hline 11. & Dedicated personnel and budget made available & Not enough budget and personnel \\
\hline 12. & $\begin{array}{l}\text { High demand from the local community/students on disaster } \\
\text { risk reduction education for children }\end{array}$ & Other, please specify \\
\hline 13. & Other, please specify & \\
\hline
\end{tabular}

\subsection{Focus group discussion with NGOs}

The FGD was organised with five child-focussed development agencies that promote the implementation of DRR education in Indonesia: UN Office for Coordination of Humanitarian Affairs (UN OCHA) representing CDE, Plan International (Plan), UNICEF, Save the Children (STC), and World Vision Indonesia (WVI).

Two other organisations (Indonesia Red Cross and Child Fund International) were also invited to participate. However, one agency did not respond to the invitation and the other was unable to attend due to unforeseen circumstances.

Five people (three males and two females), one from each organisation, participated, which is considered an ideal number for FGD on non-commercial topics (Krueger and Casey, 2015). The small size allowed time for in-depth discussions and clarifications. The participants were middle to senior level staff with more than 7 years of experience implementing DRR projects in Indonesia.

The aim of the FGD was to strengthen and triangulate data on the barriers and challenges in implementing DRR education as identified through the school personnel questionnaire. A series of discussion topics was developed based on the findings of the primary school personnel questionnaire and also the lead author's experience of working as an NGO and CCDRR practitioner. However, as is best practice with in-depth qualitative research, it was also the intention for participants to discuss other topics they felt were important to ensure coverage of a wide range of issues related to CCDRR (Kitzinger, 1995). Topics explored in the FGD included participants' views of their agencies experiences and understanding of CCDRR; the successes, barriers and challenges to implementation, sustainability and scaling up; strategies used to overcome barriers and challenges; and other issues linked to sustainability and scaling up.

FGD participants were briefed on the nature of the research, including its purpose and ethic measures approval. Participants were also asked for their permission to be audiorecorded.

The lead author's background in working for a childfocussed NGO in Indonesia enabled an informal and relaxed environment that was intended to facilitate an honest and critical discussion. However, it was also recognised that the lead author's involvement as moderator of the FGD could create bias due to his knowledge of CCDRR programmes and past employment with NGOs. To avoid this, and to promote increased data collection rigour following FGD methodological recommendations, the lead author had a very limited role in the discussions. That is, this involvement included only prompting and providing probing questions when needed, 
thereby avoiding the temptation to contribute his own perspectives (as shown in Barbour, 2010; Morgan, 2012).

The FGD was held in a UN meeting room that is a "neutral" and familiar space for the participants. All participants were active in the FGD and shared their own perspectives and experiences. The discussion lasted for $1 \mathrm{~h}$ and $40 \mathrm{~min}$.

The audio recording was transcribed verbatim and the transcripts analysed with the use of the qualitative data analysis software, QSR NVivo $10^{\circledR}$, using a thematic and inductive approach.

\subsection{Student questionnaire}

The questionnaire for students was designed to assess children's interest and knowledge on DRR. It comprised 40 items drawn from previous research and theory and included questions to ascertain demographic information, DRR-related awareness, risk perceptions, emotions, and attitudes about DRR, participation in school- and home-based preparedness for hazards, and a knowledge test (see Supplement). It is beyond the scope of this paper to present all of the results from the children's questionnaire. However, 24 questions have been chosen to establish whether or not children should be included in DRR programmes, based on their current knowledge and desire to be involved. This information will be used to contrast against the school personnel's perceptions in order to identify any issues that may result in challenges of implementing DRR programmes. The results presented here are garnered from the questions related to the knowledge test (questions 21-40) and children's interest in DRR (questions $6,16,19$, and 20).

The knowledge test questions related to fire prevention and safety, flood preparedness and response, and hygiene behaviour. These topics were selected based on the hazards that often occur in the study location (i.e. fire risks and floods). Hygiene behaviour questions were added as the children are often at risk from secondary hazards (i.e. water-borne diseases) after floods (WHO, 2013).

The student questionnaire was administered to $140 \mathrm{stu}-$ dents in grades 4 and 5 in Kembangan Selatan 2 Pagi Public Primary School. The age of students ranged between 9 and 12 years, with the exception of one student who was 14 years of age $(M=10.48, \mathrm{SD}=0.76$; comprised of 73 girls and 67 boys). Children of these age groups were selected because they have sufficient communication abilities to respond to simple inquiries (Bell, 2007; Borgers et al., 2000).

This school was selected because the school principal had taken part in the school personnel questionnaire. Thus, initial rapport was built and permission granted for this research to be conducted with the students. Furthermore, the school for this study is part of the government-endorsed safe school programme supported by a local NGO and is an at-risk school for annual flooding. In early 2014, there were two occasions where the floodwater reached $1 \mathrm{~m}$ in depth, forcing the school to be closed for a week on both occasions.
At the time of the study, there were 408 students (204 girls and 204 boys), ranging from 6 to 15 years old, enroled at the school with 1 school principal (female), 22 teachers (11 female and 11 male), and 2 school guards (both male).

Options of "I'm not sure", "I don't know", and "Other, please specify" were provided to reduce pressure and avoid participants answering randomly, as with the primary school personnel questionnaire.

The student questionnaire was reviewed by several academic experts who have experience in developing and validating questionnaires. It was also pilot-tested with 182 children in five schools in North Jakarta as part of a baseline study conducted by Save the Children (2014).

The pilot survey showed that some children were having difficulties writing responses in open-ended questions and also that their concentration was reduced if the process took over an hour. Therefore, the number of open-ended questions was minimised and the total questions restricted to shorten the process. The final questionnaire had 40 items. In this research, only relevant results are presented that are related to children's knowledge and their interest on DRR. Considering the changes made to the questionnaire, the results of the pilot survey are not included in the analysis presented here.

The questionnaire was administered during class time over a 2-day period in early January 2015, prior to the peak of the monsoon season (usually expected in early February). The data collection took under $1 \mathrm{~h}$ each day.

The survey participants sat in the class room while the facilitator read out loud the questionnaire in front of the class. Beforehand, the facilitator explained the purpose of the research project, how to mark their answers, the expected duration, and most importantly that their involvement was entirely voluntary. The participants were also informed that their responses would not affect their academic standing.

The whole process was supervised by a teacher. During the process, discussion about question clarification was encouraged. However, no discussion or deliberation between students about their answers occurred. Data were entered and analysed using Microsoft Excel.

Scoring criteria were developed to classify participants according to the level of knowledge into the following groups: high, medium, and low (Table 3). For example, participants who selected three correct answers (out of five questions) in relation to hygiene were rated as having a medium level of knowledge. This classification was used to differentiate children with a high level of knowledge in DRR and others who require more learning.

\section{Results}

The following section describes the results from the three stages: survey questionnaires with school personnel and children, respectively, and FGD with child-focussed NGOs. Re- 
Table 3. Criteria for classifying children's knowledge and skills.

\begin{tabular}{llrrrr}
\hline \multirow{2}{*}{ No. } & Type & \multicolumn{3}{c}{ Number of correct answers } & Total \\
\cline { 3 - 4 } & & Low & Medium & High & questions \\
\hline 1. & Fire prevention and safety & $0-2$ & $3-4$ & 5 & 5 \\
2. & Flood preparedness and response & $0-5$ & $6-8$ & $9-10$ & 10 \\
3. & Hygiene behaviour & $0-2$ & $3-4$ & 5 & 5 \\
4. & Overall & $0-9$ & $10-18$ & $19-20$ & 20 \\
\hline
\end{tabular}

sults are divided per theme and the FGD results include participants' quotes.

\subsection{Questionnaire: school personnel}

\subsubsection{Children's involvement in DRR}

The results illustrate that the majority of teachers are confident in their abilities to involve children in the disaster preparedness process $(86 \%)$, believe that children should learn DRR education in schools (68\%), and consider children to have an important role in disaster preparedness $(89 \%)$. The majority of teachers also think that children should be involved in developing preparedness plans for their homes $(61 \%)$ and school $(57 \%)$.

However, when it comes to children's involvement in DRR, the views of teachers are divided, with $45 \%$ considering that this might increase the risks faced by children and $39 \%$ believing that children should not be actively involved.

\subsubsection{Factors in implementing DRR education}

Eight facilitators and five deterrents (shown in italics in Table 4) were selected by more than one-third of participants. Hence, these are considered as key factors. Moreover, twothirds of participants $(69 \%)$ selected more than one option. While inspection of Table 4 underscores this point, a few factors stand out as more important, with the highest response being teachers training availability.

\subsubsection{Preferences on type of teachers' training}

When asked whether they were interested in training if it were offered and did not impinge unduly on their time, all participants answered yes $(100 \%)$. A blended or combination approach involving a mixture of classroom (theoretical approach) and experiential training received the highest endorsements (50\% of 44 responses), with "experiential or hands-on" training receiving the highest score for a single method $(38 \%)$.

\subsubsection{Partnerships with other stakeholders}

More than one-third of the participants (37\%) think that the level of coordination between their schools, the local council, and the disaster management agency is non-existent to low, $36 \%$ believe there is a medium level of coordination, and $25 \%$ stated that the coordination level is high. However, $75 \%$ of participants indicated that they desired future changes to the level of coordination between these stakeholders whereas $18 \%$ did not. The remaining participants did not answer the question. Of those who answered yes, two-thirds provided reasons of which, $45 \%$ were related to improvement in disaster response, and $32 \%$ in relation to disaster preparedness.

\subsection{Questionnaire: children}

\subsubsection{Perspectives of children of their knowledge - what they think they know as opposed to what they actually know}

Most children correctly identified the hazards that may impact their homes $(79 \%, n=140)$ and their school $(62 \%)$, i.e. earthquake, floods, strong wind, structural fires, high tide, disease outbreak, riot, conflict, or violence (as per Dickson et al., 2012; Tadjoeddin, 2002; WHO, 2005). The remaining proportion of children identified hazards that are not likely to impact their homes or school, i.e. tsunami, landslides, volcanic eruption, drought, or forest fire.

The majority ( $71 \%$ ) of children indicated that they think they know how to be safe, $14 \%$ do not think they know how to be safe, $14 \%$ were not sure, and $1 \%$ did not answer the question. Nearly all children think that they can or maybe can make themselves (94\%) and others (91\%) comfortable or calm in an emergency. However, the majority of children $(61 \%)$ also stated that they are sometimes worried, scared, or upset when thinking or talking about disasters.

The results of the knowledge test (see methodology for scoring criteria) illustrate that $89 \%$ children have a medium level of overall knowledge, scoring best on flood preparedness and safety, where $26 \%$ received a high score. However, the children scored poorly on knowledge in other areas, where only 2 and $15 \%$ of children received a high score on hygiene behaviour and fire prevention and safety respectively.

When comparing the knowledge test results of the $71 \%$ of children who indicated that they know how to be safe from disasters, nearly all of them (96\%) scored in the low- 
Table 4. Teachers' responses to facilitators and deterrents in implementing DRR education in their classroom (participants were able to select more than one factor). Text shown in italics are factors that were selected by more than one third of participants.

\begin{tabular}{|c|c|c|c|c|}
\hline No. & Facilitators & $\begin{array}{l}\% \text { of respondents } \\
\qquad(n=44)\end{array}$ & Deterrents & $\begin{array}{r}\% \text { of respondents } \\
(n=44)\end{array}$ \\
\hline 1. & $\begin{array}{l}\text { Training available on how to develop } \\
\text { and/or deliver such programmes for } \\
\text { children }\end{array}$ & $84 \%$ & $\begin{array}{l}\text { No clear mandate and/or policies to im- } \\
\text { plement disaster risk reduction educa- } \\
\text { tion for children }\end{array}$ & $52 \%$ \\
\hline 2. & $\begin{array}{l}\text { Good partnerships between schools, } \\
\text { disaster management agency, and local } \\
\text { councils }\end{array}$ & $57 \%$ & $\begin{array}{l}\text { Lack of training in developing and/or } \\
\text { delivering programmes of this sort }\end{array}$ & $52 \%$ \\
\hline 3. & $\begin{array}{l}\text { Innovative methods for curriculum in- } \\
\text { clusion (e.g. combining learning with } \\
\text { school drills) }\end{array}$ & $52 \%$ & $\begin{array}{l}\text { Lack of "ready-to-go" and "child- } \\
\text { friendly" teaching resources }\end{array}$ & $48 \%$ \\
\hline 4. & $\begin{array}{l}\text { Availability of useful "ready-to- } \\
\text { go" and "child-friendly" teaching } \\
\text { resources }\end{array}$ & $50 \%$ & $\begin{array}{l}\text { Lack of knowledge in developing cur- } \\
\text { riculum for disaster education }\end{array}$ & $41 \%$ \\
\hline 5. & $\begin{array}{l}\text { Clear policies for school to deliver dis- } \\
\text { aster risk reduction education for chil- } \\
\text { dren }\end{array}$ & $48 \%$ & $\begin{array}{l}\text { Weak coordination between schools, } \\
\text { disaster management agency, and local } \\
\text { councils }\end{array}$ & $36 \%$ \\
\hline 6. & Personal interest in the topic & $41 \%$ & Not enough space in the curriculum & $30 \%$ \\
\hline 7. & $\begin{array}{l}\text { Promotion on the teaching resources by } \\
\text { other teachers or education personnel }\end{array}$ & $39 \%$ & Not enough budget and personnel & $30 \%$ \\
\hline 8. & $\begin{array}{l}\text { Dedicated personnel and budget made } \\
\text { available }\end{array}$ & $36 \%$ & $\begin{array}{l}\text { The topic is not a priority by the school } \\
\text { management }\end{array}$ & $25 \%$ \\
\hline 9. & $\begin{array}{l}\text { Topic is timely in relation to upcoming } \\
\text { risk for local natural hazards (e.g. bush- } \\
\text { fire, fire, cyclone, flooding seasons) }\end{array}$ & $23 \%$ & $\begin{array}{l}\text { Not compatible with my beliefs about } \\
\text { what children should learn in school }\end{array}$ & $7 \%$ \\
\hline 10. & $\begin{array}{l}\text { The topic becomes a priority by the } \\
\text { school management }\end{array}$ & $14 \%$ & Lack of interest from the community & $5 \%$ \\
\hline 11. & $\begin{array}{l}\text { High demand from the local commu- } \\
\text { nity/students on disaster risk reduction } \\
\text { education for children }\end{array}$ & $11 \%$ & Other & $5 \%$ \\
\hline 12. & Student interest in the topic & $5 \%$ & The topic is not relevant for the students & $2 \%$ \\
\hline 13. & Other & $5 \%$ & & \\
\hline
\end{tabular}

to-medium range of knowledge, with only $4 \%$ having knowledge of DRR in the high range.

Even though this research did not investigate in-depth on the issues of DRR education in this specific school, based on observation and discussion with the school personnel, this low score may be due to the fact that teaching material related to DRR is inconsistent with the key messages provided by the government, a lack of capacity among the teachers to search for DRR material, and the DRR education programme is limited to awareness raising and disaster simulation exercise.

\subsubsection{Participants' interest in DRR education and involvement in preparedness}

Nearly all child participants (94\%) would like to know more about how to stay safe. The reasons given for wanting more knowledge were grouped into three themes: to know how to be safe for themselves (e.g. "Because I want to know how to be safe from disasters"), to overcome their fears in relation to natural hazard impacts (e.g. "Because I fear drowning and many diseases"), and to protect oneself, other people, and the surrounding areas (e.g. "Because if it [a disaster] happens, I want to save my family and neighbours"). Only one participant gave a coherent reason for not answering "yes" and that was that the child did not want the disaster to happen in the first place.

A large majority of participants (more than $80 \%$ ) would like to be involved in making their school and home more prepared for disasters. From the participants who answered "no", only a few provided clear reasons, which were "I have never experienced disasters", "I do not want to be affected by disaster", "because mom and dad would not allow me [to be involved in preparedness activity]", and "because it [being involved in preparedness activity] makes things difficult".

\subsection{FGD with child-focussed NGOs}

During FGDs, participants shared their CCDRR project experiences, including efforts in promoting DRR education. 
They also described successes and progress coupled with the challenges they have faced. Based on the discussions, the findings were categorised into four main issues. The following section described each of the main issues.

\subsubsection{Programme delivery approach}

During the discussion on the NGOs' experiences in implementing CCDRR, several main obstacles were identified. The first is that NGOs face a significant challenge to sustain DRR projects when funding ceases. Participants labelled this a "project mentality" problem.

Sustainability. Well, it is easy to say it but to realise it is very hard... our weakness is in monitoring after the project is finished, especially project areas where we do not have regular office presence.

The participants mentioned that most international NGOs do not have a long-term office presence at the local (or district) level and, according to participants, lack a strategy or vision to ensure sustainability in the Indonesian context. When the programme ends, the office is closed and staff relocated. Participant discussion also confirmed that the current government's monitoring system does not assess implementation or evaluate progress and effectiveness of DRR programmes in schools.

\subsubsection{Funding limitation for comprehensive package of safe schools programme}

Participants stated that NGOs usually have limited funding. Hence, efforts are often limited to delivering singular activities versus more comprehensive packages of education and teachers' training. Training and/or emergency drills were highlighted as the common activities facilitated and conducted. These were echoed several times, with the activities being reported to be one-off events, without exception. There were also challenges in implementing a comprehensive approach for school safety:

In a safe school package there are a range of activities from A to Z, maybe we can only implement from $\mathrm{A}$ to $\mathrm{D}$, not the whole package. ... the simplest activity is to conduct a disaster simulation... to expect implementing one full package like we want, we still have not been able to do it.

When NGOs do succeed in advocating with local government to allocate funding for DRR implementation, the funding is often small, with reports of competing development priorities as one source of this problem:

The reality is that certain districts have limited funding. So, we face tough choices. Which one that needs to be included in their development priorities, and when we talk about DRR, this goes to the back [and not as a priority].
This inevitably restricts the ability to implement a comprehensive package for a school-based DRR programme.

However, some participants disagreed in relation to funding issues. One participant mentioned that funding is available, particularly at the national level. As another participant stressed, the issue is not about budget but more a lack of understanding and capacity of government officials associated with engaging and promoting children's participation. However, one participant pointed out that there are opportunities for funding at the local level by tapping to the village funds.

\subsubsection{Political will from the government}

Participants discussed their frustration with the current and past government administrations, including DRR and education agencies, which still view children as passive participants:

... even in [disaster] preparedness activities [such as disaster simulations]... most of the time they are being treated as objects...

The Disaster Management Agency and the Ministry of Education have not made the issue of children and DRR a focus. This, combined with a lack of policy or political will, was considered a hindrance to the implementation of DRR education in schools:

The government does not have a specific focus on children, especially in the disaster sector. Until now, even in emergency response, vulnerable groups have not been the focus.

Up to this day, we still have problems with the Ministry of Education and the Curriculum Centre. They still do not have the solid "political will" for our [DRR] education system. So, we could not expect the schools to sustain it.

Nevertheless, moving beyond a project mentality is an issue that all participants want to focus on. Participants emphasised the importance of involving and working alongside government officials. A crucial step for NGOs, to ensure the sustainability of a programme and create a sense of ownership, was considered to be establishing relationships with government from early in the development of a project. However, participants noted the challenge in maintaining relationships. This included engaging and building the capacity of selected individuals in an agency as they are commonly transferred (every 2 to 3 years) to other agencies in different sectors, thus taking the knowledge and institutional memory of that collaboration with them. To anticipate this, participants recognised the importance of long-term implementation planning to secure commitments and anticipate government turnover. 


\subsubsection{Targeting the right partners}

According to participants, identifying with whom you are working with in government is also essential. Participants described an example when they advocated for DRR to be integrated in the national curriculum:

Let's take for an example, SCDRR [Safer Community through Disaster Risk Reduction]. They [SCDRR project team] spend lots of money to develop the modules but that still does not guarantee success. They start through the Curriculum Centre, but other directorates who oversee the schools won't buy it.

The participants described that in 2010, the United Nations Development Programme in collaboration with CDEsupported advocacy efforts through the project SCDRR. They worked closely with the Curriculum Centre, a unit within the Ministry of Education who hold the authority in designing the national curriculum.

However, a different set of units, the primary education and secondary education directorates, oversee the implementation of policies in primary and secondary education. These directorates were not involved in the previous stage described; there was thought to be a lack of awareness and low sense of ownership from these directorates to enforce DRR-related policies in the schools, as perceived by FGD participants:

... at the national level, there have been plenty of guidelines. Now, it is more on how we can implement it and enforce the policies.

Participants also acknowledged that there are a lot of actors that should be involved in DRR education, including different units within the Ministry of Education and other agencies (e.g. the National Disaster Management Agency, Ministry of Religious Affairs, and NGOs) who have relevant experiences and interests. Therefore, building inter-agency collaboration and having support from the top level was considered essential. This is a similar approach being undertaken in the water and sanitation sectors in Indonesia, as described by a participant. In addition, some participants mentioned the value of building a coalition at the national level in order to strengthen the efforts to ensure children's views reach the government:

The Children in a Changing Climate Coalition has already existed for a long time and this is not donor driven, but because we believe that children can be agents of change... Maybe, that is an interesting idea [establishing coalition at the national level] because there are a lot of players [who have similar interests].

\section{Discussion}

Overall, the results from the children's survey on the low score received on knowledge and skills test have shown the importance of DRR education as well as their high interest to learn more; meanwhile, results from the survey with school personnel and FGD with the NGOs highlight the challenges in implementing DRR in schools.

The children's survey results suggest that the majority of children (1) have an awareness of the hazards surrounding them, (2) believe they know how to stay safe from those hazards, and (3) want to be involved. However, nearly all children attained scores within the low-to-medium range on the knowledge test, scoring poorly on hygiene and fire-related topics. Additionally, more importantly, most of these children think that they know enough on how to stay safe from disaster. This is an important finding that suggests children have a lack of knowledge in DRR even though they might have a sense of hazard awareness and believe that they know how to stay safe in a disaster.

Having a level of hazard awareness is an important and an initial step to become better prepared (Bird et al., 2009; King, 2000; Paton et al., 2008). However, previous studies have demonstrated that a high level of awareness does not mean that the public have the correct knowledge, are able to practise it when needed, or are necessarily better prepared (e.g. Haynes and Tanner, 2015; Whittaker et al., 2013). This is because there are many other factors at play, not least underlying vulnerabilities. This can be as important as knowledge in influencing behaviour and outcomes in relation to risk reduction (Bird et al., 2011; Haynes et al., 2008; Whittaker et al., 2013).

As evidenced by the results presented here, there are various factors that need to be considered when implementing DRR education in Indonesia. The five deterrents and eight facilitators have been synthesised into six key issues related to the implementation of DRR education in Indonesia (Table 5). Interestingly, children's interest is not considered as a factor of influence. However, the children's survey shows that they have a strong interest to learn about DRR. This is an important issue to keep in mind for schools considering the value of these programmes. This has therefore been presented in Table 6 as the seventh factor. Each of these seven key issues is discussed in the following sections.

\subsection{Policy on DRR education in Indonesia}

More than half of the school personnel participants think there are no clear mandates and/or policies on DRR education. This indicates the lack of awareness or clarity on DRR education policies, as Indonesia already has policies supporting DRR education. The law on disaster management (act no. 24 of 2007) has provided the legal framework that all citizens have the right to receive DRR education in Indonesia. In 2010, an endorsement letter by the Ministry of Edu- 


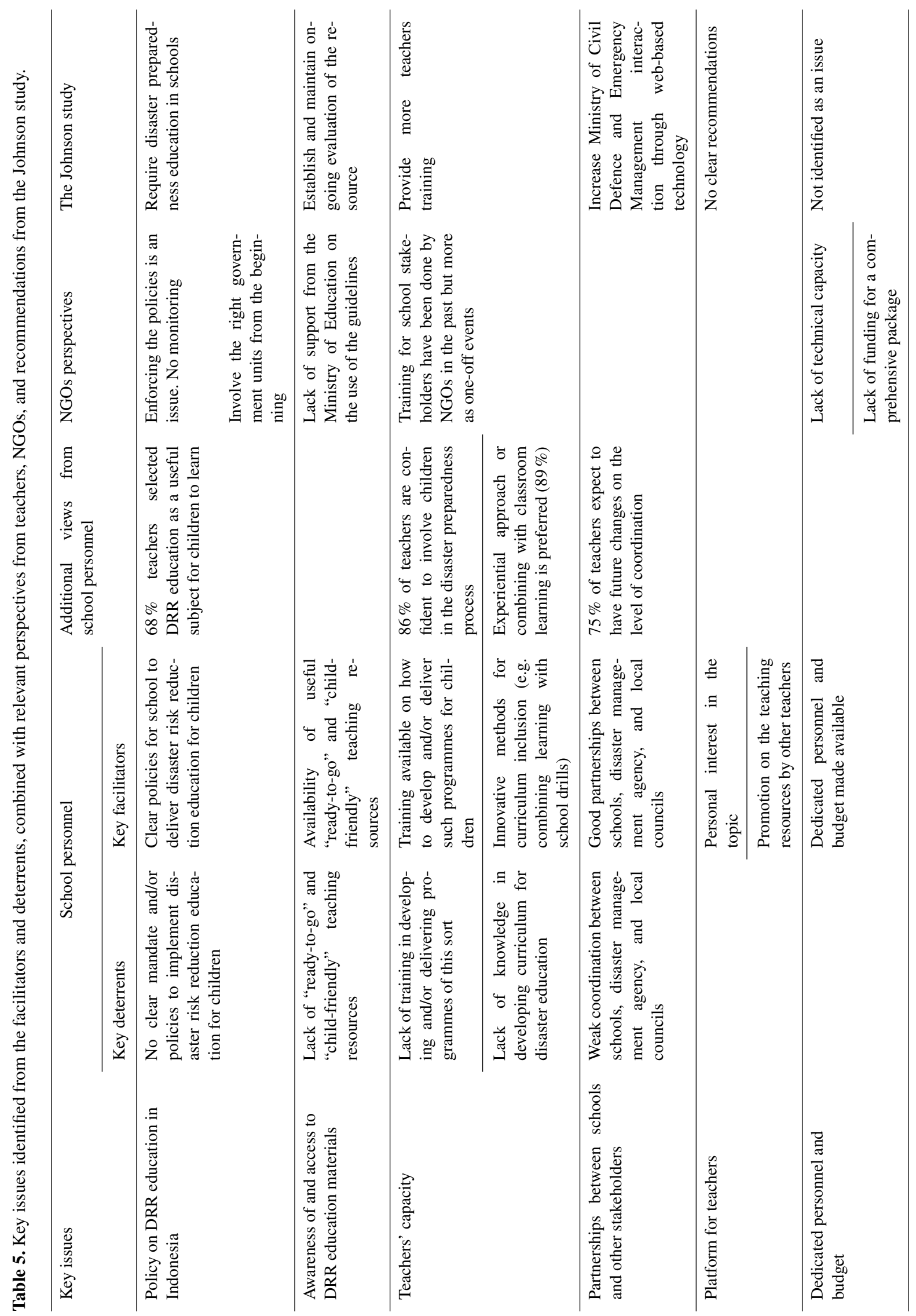


Table 6. Perspectives on children's participation in DRR.

\begin{tabular}{|c|c|c|c|c|}
\hline Key issues & Teachers' perspectives & Children's perspectives & NGOs' perspectives & The Johnson study \\
\hline \multirow[t]{3}{*}{$\begin{array}{l}\text { Children's participation } \\
\text { in DRR }\end{array}$} & $\begin{array}{l}45 \% \text { of teachers think } \\
\text { that involving children } \\
\text { will put children at } \\
\text { greater risk }\end{array}$ & $\begin{array}{l}94 \% \text { of children would } \\
\text { like to learn more on } \\
\text { DRR }\end{array}$ & $\begin{array}{l}\text { Children are still seen } \\
\text { as passive participants }\end{array}$ & $\begin{array}{l}\text { Not discussed in the } \\
\text { study }\end{array}$ \\
\hline & $\begin{array}{l}39 \% \text { of teachers think } \\
\text { children should not be } \\
\text { actively involved }\end{array}$ & $\begin{array}{l}>80 \% \text { of children want } \\
\text { to be actively involved } \\
\text { in preparedness at } \\
\text { home and in schools }\end{array}$ & & \\
\hline & $\begin{array}{l}89 \% \text { of teachers be- } \\
\text { lieve that children have } \\
\text { an important role in dis- } \\
\text { aster preparedness and } \\
\text { will benefit children }\end{array}$ & & & \\
\hline
\end{tabular}

cation of Indonesia (2010) (the circular letter of the Minister of National Education no. 70a/SE/MPN/2010) was sent to all education offices in Indonesia encouraging schools to mainstream DRR education using three options (through existing subjects, local content, and/or extracurricular activities). In 2012, BNPB also produced guidelines on safe schools. In addition, DRR has been incorporated in the national curriculum from primary to secondary schools, starting from grade 4 (the Curriculum Centre or Pusat Kurikulum, 2009). The nature of these policies is not imposing but more encouraging. This is because Indonesia has a decentralised system where the central government has less authority compared to the district government over education content, financial matters, and school practice.

This situation is similar to that identified on the national implementation of a CCDRR programme in New Zealand, where a programme kit was sent to every primary school in the country. However, as the programme is entirely voluntary, uptake has been quite low (Johnson et al., 2014). Similarly, child-focussed NGOs appeared to appreciate the development of a national policy but equally lamented that it is not being implemented in a systematic manner. This reflects a more pervasive problem in this area across the HFA with numerous countries developing DRR, or CCDRR, policy that is more "aspirational" than realised (Ronan, 2014).

This highlights a failing of the current monitoring system to capture the progress on the implementation of the policies related to DRR education. It is also worth noting that a systematic review of the 35 CCDRR education programme evaluations found that none of these were evaluated locally by DRR professionals, schools, or local community stakeholders (Johnson and Ronan, 2014). All were done by professional evaluators, with over $90 \%$ being those in higher academic settings. This is a problem seen in many countries, especially on NGO-led projects, where the HFA has spurred the progress of the implementation of CCDRR education programmes and other areas (Ronan, 2014). This state of affairs represents a significant barrier for scaling up and ensuring sustainability.

\subsection{Awareness of and access to DRR education materials}

Half the participants from the school personnel survey stated that the availability of "ready-to-go" and "child-friendly" DRR education materials will aid the implementation of DRR education. This suggests that there is a lack of access to and awareness of already available DRR materials. For example, Pusat Kurikulum (2009) has produced guidelines for teaching on five main hazards (earthquake, floods, landslide, fire, and tsunami) in Indonesia. There are also a variety of guidelines and teaching resources produced by agencies such as the Indonesian Red Cross (2009) and Save the Children (2007b).

A further issue is that there are no standards for approved "key DRR messages" in educational resources for the Indonesian context. That is, there is no system in place to control and assure the quality of resources related to childcentred education frameworks, content, and delivery mechanisms in Indonesia, even though it is vital to have standard and/or consistent key messages (Ronan et al., 2001, 2010; Ronan and Johnston, 2003; Shimura and Yamagata, 2015; UNESCO, 2014). For examples of key DRR messages see IFRC (2013).

The current results also demonstrate that school personnel favour the inclusion of innovative methods for delivering DRR education. Practitioners of CCDRR have developed several participatory tools for children (e.g. risk mapping, transect walks, participatory video, mind mapping) to identify, assess, and communicate risks and generate action to bring about changes in communities (see Haynes and Tanner, 2015; Molina et al., 2009; Plan International, 2010). These tools should be considered for inclusion in the resource materials for DRR education in schools. 
As a result of current findings, combined with previous research and expert opinion (IFRC, 2013; UNESCO and UNICEF, 2012, 2014) it is important that these standard key messages and innovative methods are included in the new curriculum when it is rolled out in 2016.

\subsection{Teachers' capacity}

A significant percentage of teachers $(84 \%)$ described a belief that training will help them facilitate the implementation of DRR education in their classroom or school. This percentage is much higher than for other facilitating factors. Some teachers are confident in their abilities to involve children in the disaster preparedness process. However, almost half believe that involving children will put children at greater risk. This is in line with the findings on teacher's perspectives in the aftermath of the 2011 Christchurch earthquake (Johnson and Ronan, 2014) as well as previous studies in Indonesia (Desfandi, 2014; Sopaheluwakan et al., 2006).

Furthermore, training teachers in DRR poses a significant challenge for Indonesia with more than 17000 islands and 269000 schools (Ministry of Education and Culture, 2012), spread over 34 provinces comprised of 413 districts and 98 cities. A cascading method has been used in Indonesia to roll out training for teachers, where training of trainers (ToT) is organised and the trainers that have been produced from this ToT continue to train other teachers (UNESCO and UNICEF, 2012). However, this option requires a significant number of master trainers and trainers for teachers. If the target were to train at least one teacher of each Indonesian school, almost 9000 training sessions would be needed, with a maximum of 30 participants per training. This number excludes training for trainers and associated monitoring components.

A systematic way to improve teacher's capacity is by integrating DRR education in higher-education programmes for teachers. UNISDR (2008) considers this the most effective, least expensive, long-term, and sustainable approach. This way, every teacher will have basic knowledge and skills to teach DRR. Another way is through online or computerbased training, though noting that this was not a preferred option from the school personnel survey, it has been found effective in reaching a large number of teachers over a short period of time in Turkey (Petal and Sanduvac, 2012).

\subsection{Platform for teachers}

As it stands currently, the quality of DRR education in schools depends on teacher's willingness and creativity. This is reflected in the survey where personal motivation and promotion of education resources by other teachers are seen to be facilitating factors. Encouragingly, the survey results show that the majority of teachers believe children have an important role in disaster preparedness and that it will bring benefits to children (although noting as well that some teachers think that it may put the children at risk).

Johnson and Ronan (2014) revealed that peer-to-peer support among teachers could be an effective mechanism to help teachers implement DRR education. Having teachers that are more knowledgeable and regarded as "champions" on DRR education could inspire other teachers to follow in their footsteps.

The Disaster Resilient Australia New Zealand School Education Network (DRANZSEN) is made up of teachers, researchers, emergency service managers, and policy makers and is intended to strengthen the relationship and feedback between these spheres and also promote developments in DRR education (Attorney General's Department, 2015). This sort of network serves as an ideal platform with regular faceto-face meetings that could be broadened via an online presence to include Indonesian users. Alternatively, the platform could be replicated to connect teachers involved in DRR education across Indonesia. Creative tools that have been produced such as the ones documented by Back et al. (2009) and Dicky et al. (2015) could also be shared in such a platform.

The Indonesian government builds national identity among young people in schools through various approaches. Every Monday morning, all school children have to perform flag raising ceremonies and sing the national anthem, and every Friday all school children undertake morning aerobics with specific choreography that enhances citizenry (Moser, 2015). These approaches, which are repetitive in nature, can also be replicated to instil preparedness and risk reduction knowledge. For example, school principals can disseminate preparedness messages to warn students on the upcoming rainy season during the flag ceremony. Another way to reinforce this linkage is by organising a competition at the national level for the most disaster-prepared schools. Studies indicate that friendly competition between schools can improve the quality of teaching and school performance (Hanushek and Rivkin, 2003; Wößmann, 2007). Similar competitions have been successfully implemented by the health sector, with a government-run "healthy school" competition held annually at the national level (Direktorat Jendral Pendidikan Dasar, 2015).

\subsection{Partnerships between schools and other stakeholders}

According to the teachers' survey, more than half of the participants think that a good partnership between the school and the council/disaster management agency is a facilitating factor in the implementation of DRR education in schools. However, a higher number of teachers still think the roles of the local council and disaster management agency are mainly for improved emergency response, when in fact they also have a role in building preparedness.

Joint activities can be in the form of developing preparedness planning together, conducting joint simulations, and for 
school children to raise awareness in the surrounding community. Framed as "being prepared to respond" to appeal to teachers' views could be useful to increase the effectiveness of preparedness measures in schools and the surrounding community (Towers et al., 2014).

Another way to strengthen partnerships is through the local DRR forum, a multi-stakeholder platform serving as a coordination mechanism to enhance collaboration. Schools that have DRR education programmes should be part of any local DRR forum to enable dialogue and partnerships with other forum members (e.g. the fire department, search and rescue, Red Cross) who have specific skills and expertise related to DRR. These agencies can be invited to share their experiences and also provide trusted and credible information for the students regarding DRR.

\subsection{Dedicated personnel and budget}

One of the facilitating factors identified is having dedicated personnel and a budget to implement DRR education. However, since DRR is already integrated in the curriculum, there should be no reason for teachers not to implement DRR education, even when there is a lack of dedicated DRR funding.

However, lack of funding may influence DRR activities beyond simply teaching DRR to students, as suggested by the result from the child-focussed NGOs. A comprehensive package of safe schools, as illustrated by GADRRRES and UNISDR (2014), would require additional funding. This includes other interventions such as retrofitting of school buildings, disaster simulations, teacher training, inviting experts to schools, and developing school disaster management plans.

\subsection{Child participation}

Students and/or community interest were factors that had little influence on teachers' views on the facilitators and deterrents in DRR education. This indicates that teachers seem to be indifferent to the interest (or lack of interest) from the students and/or the community on DRR education. This could be because there is more pressure to make sure that students can perform on exams or other reasons. However, this requires further investigation. This perhaps illustrates a style of teaching which may be dominated by a "top-down" approach, resulting in reduced interest or understanding of the benefits in hearing the views from the community, including children.

Some teachers $(39 \%)$ also disagree with children being actively involved in preparedness planning. This result may come from the participants' understanding of the meaning of "active participation", which can be ambiguous and worthy for future investigation (i.e. what does "active participation of children" mean to different stakeholders?). Nevertheless, this presumption was strengthened by the childfocussed NGOs where children are still seen as passive participants, and it is potentially a significant obstacle to chil- dren's participation in DRR through schools or classrooms where this perception is prevalent.

This is contradictory to the result from the children's survey which demonstrated that the vast majority of children were interested in learning more about DRR and assisting to ensure their schools (and homes) are safer from disasters. The right for children to participate is protected in the Child Protection Law of the Government of Indonesia (2002) and the UN Convention on the Rights of the Child (1989). There are also many documented case studies and preliminary research findings which demonstrate that children's active involvement brings added value, including to the resilience of the community (Amri, 2015).

Many of the children living in Jakarta are prone to natural hazards. This is a risk to their safety and wellbeing as well as access to essential services such as health and education. Therefore, taking into account the views from the children, it is clear that DRR education in schools will enhance their rights to both safety and to participate. Greater awareness is also needed among teachers on the benefits of children actively participating in efforts to reduce risk in their schools and homes, perhaps through teachers' training.

This study focuses specifically on Indonesia, particularly the urban setting of Jakarta. However, these key issues may well be apparent in many other developing and developed countries, as highlighted by Ronan et al. (2010) and Johnson et al. (2014). These issues include the need for structured DRR training for teachers, a lack of awareness and access to materials, and issues associated with partnerships with other stakeholders. Hence, the recommendations suggested in this paper may well be applicable beyond Indonesia.

\section{Limitation of study and future research}

This study involves a relatively small sample size of school personnel and NGO staff and focuses only on Jakarta. Nevertheless, the school personnel that took part in the survey were from schools classified as at risk to floods and selected by the Jakarta Province Disaster Management Agency. The NGO staff were senior managers with more than 8 years of experience in implementing CCDRR in many areas in Indonesia and also from reputable child-focussed agencies. Thus, the responses from NGO staff have strengthened the discussion and the recommendations. This combination has provided a more comprehensive overview of the issues related to DRR education in Indonesia, compared to previous studies by Desfandi (2014) and Sopaheluwakan et al. (2006).

Plans for further research using a longitudinal approach are underway, including (1) expanding the sample size (more schools in Jakarta with diverse characteristics, including type of schools - i.e. public, private, and religious schools - status of DRR education programme - i.e. have ongoing DRR education programme versus those with no DRR education programme - support from outside the school (NGO-supported, 
local-government supported, and no support), and types of exposure - i.e. school is frequently flooded, school is safe but the surrounding area is flooded, access to school disrupted due to floods), (2) additional stakeholders (parents and government officials), (3) assessing wider topics of DRR (including disaster prevention, mitigation, and climate change adaptation), and also (4) replicating the study in other areas in Indonesia.

\section{Conclusions and recommendations}

This study developed and tested tools to assess children and teachers' perspectives and knowledge on DRR and advances from previous studies implemented in the context of a developed country. The tools developed were applicable to the Indonesian context and the results have generated a number of actionable recommendations (see below). The results highlight the strong desire for children to learn more on how to stay safe from disasters and reduce disaster risks in their communities. It also demonstrates that children are extremely interested in assisting their households and schools to become better prepared for disasters. However, there is still a gap in children's knowledge on DRR. Seven key issues on implementing DRR education in Indonesian schools were identified based on the perspectives of children, school personnel, and child-focussed NGOs. These issues relate to policies on DRR education in Indonesia, teachers' awareness of and access to DRR educational materials; teachers' capacity for implementation of DRR education in schools; partnerships between schools and other stakeholders; the lack of a platform for teachers to share experiences, successes, and challenges; dedicated personnel and budget; and children's participation in DRR education and measures.

Thus, the following recommendations, which consider aspects of sustainability and scaling up, are made based on each of the seven key issues.

1. As the authorising body, the primary and secondary education directorates should lead efforts to raise awareness of policies related to DRR education to all school personnel and other education bodies across Indonesia. The directorates should also include DRR aspects in the school monitoring process so progress of DRR implementation is evaluated and reported.

2. Teachers should have access to an online knowledge hub as a repository of educational resources, including various guidelines and teaching manuals produced by various institutions. In addition, the Ministry of Education should take the lead in conducting a critical review of DRR education, including the development of standardised key messages for DRR in schools. Infusion of relevant key messages through the weekly flag ceremony and/or weekly aerobics could be effective.
3. A live and online discussion platform should be established to connect teachers across Indonesia who have an interest in DRR education. A competition at the national level could also motivate "champions" in DRR education.

4. DRR education training should be integrated into higher-education programmes as part of teachers' professional development. Given Indonesia is a highly disaster-prone country, basic knowledge of DRR should be part of teachers' minimum competencies. Although not a popular choice, the use of e-learning and computer-based training is an option for participants who have access to the technologies.

5. Joint activities to enhance preparedness should be fostered particularly between schools and local councils and disaster management agencies. Schools should also be part of the local DRR forum.

6. Budgets should not be an issue since DRR is already part of the national curriculum. However, for comprehensive DRR activities (e.g. school retrofitting, training for teachers, school drills), schools could obtain additional funding from the village funds where the government is disbursing development funding to be managed at the village level.

7. School personnel and other education staff (including those in the emergency management sector) should be aware on the benefits of children's participation in DRR.

These findings suggest that a change of strategy and introduction of new measures are essential to improve the implementation, and effectiveness, of DRR education in Indonesia. As previously described, work is underway to expand the research - i.e. more schools, adding more stakeholders (parents and government officials), and expanding to broader topics (disaster prevention, mitigation, and climate change adaptation) and conditions (e.g. flood prone versus non-flood prone).

Results and recommendations in this research are based on an Indonesian case study. Nevertheless, challenges that were identified are in line with previous studies and, therefore, the recommendations may be applicable in other countries facing the same challenges.

Data availability. Due to ethical requirements, the data sets involve data gathered from people, including children, and are required to remain anonymous. The data are stored on a server at Macquarie University and are available upon request.

The Supplement related to this article is available online at doi:10.5194/nhess-17-595-2017-supplement. 
Competing interests. The authors declare that they have no conflict of interest.

Acknowledgements. This research was funded by the Bushfire and Natural Hazards Cooperative Research Centre (BNHCRC), Macquarie University, and Risk Frontiers. We gratefully acknowledge those who participated in this research - the children, school personnel, and NGO colleagues from SDN Kembangan Selatan 1 Pagi Jakarta, the Provincial Education Office and the Disaster Management Agency of DKI Jakarta, the Consortium for Disaster Education - who provided their wisdom and insights for this research.

We would like to thank Marla Petal, Susan Davie (VICSES), Nick Ireland (Save the Children), Lyndsey Wright (BNHCRC), Yusra Tebe, Wahyu Kuncoro, Vanda Lengkong, and Amin Magatani (Plan International), Titi Moektijasih, Mindaraga Rahardja, Riana Nedyawati (UN OCHA), and Barb Kelly for their helpful reviews, suggestions, and comments.

Edited by: T. Bogaard

Reviewed by: N. Nurdin, T. Jeggle, and one anonymous referee

\section{References}

Amri, A.: Challenges in implementing disaster risk reduction education: Views from the frontline in Indonesia, Macquarie University, Sydney, Australia, 2015.

Attorney General's Department, G. o. A.: National progress report on the implementation of the Hyogo Framework for Action (2013-2015): Australia, UNISDR, 2015.

Back, E., Cameron, C., and Tanner, T.: Children and Disaster Risk Reduction: Taking stock and moving forward, UNICEF, Brighton, UK, 2009.

Baker, J. L.: Climate Change, Disaster Risk, and the Urban Poor : Cities Building Resilience for a Changing World, World Bank, Washington, DC, 2012.

Barbour, R. S.: Focus Groups, in: The SAGE Handbook Qualitative Methods Health Research, edited by: Bourgeault, I., Dingwall, R., and Vries, R. D., SAGE Publications Ltd, London, UK, 2010.

Bell, A.: Designing and testing questionnaires for children, Journal of Research in Nursing, 12, 461-469, 2007.

Bird, D. K., Gisladottir, G., and Dominey-Howes, D.: Resident perception of volcanic hazards and evacuation procedures, Nat. Hazards Earth Syst. Sci., 9, 251-266, doi:10.5194/nhess-9-2512009, 2009.

Bird, D. K., Gísladóttir, G., and Dominey-Howes, D.: Different communities, different perspectives: issues affecting residents' response to a volcanic eruption in southern Iceland, B. Volcanol., 73, 1209-1227, 2011.

BNPB: Kajian Tentang Penanggulangan Bencana Alam di Indonesia, BNPB, Jakarta, 2009.

BNPB: Perka BNBP No. 4 Thn 2012 tentang Pedoman Penerapan Sekolah Aman Bencana, 2012.

BNPB: Pedoman Penyusunan Rencana Kontingensi Antar Lembaga Menghadapi Ancaman Bencana, 2013.

BNPB: National progress report on the implementation of the Hyogo Framework for Action (2013-2015), Indonesia, UNISDR, 2014.
BNPB: $\quad$ http://dibi.bnpb.go.id/DesInventar/dashboard.jsp? countrycode=id, last access: 18 August 2016.

Borgers, N., de Leeuw, E., and Hox, J.: Children as Respondents in Survey Research: Cognitive Development and Response Quality 1, Bulletin de Méthodologie Sociologique, 66, 60-75, 2000.

BPS: Jakarta In Figures 2014, Statistics of DKI Jakarta Province, Jakarta, Indonesia, 2015.

Brown, D. and Dodman, D.: Understanding children's risk and agency in urban areas and their implications for child-centred urban disaster risk reduction in Asia: Insights from Dhaka, Kathmandu, Manila and Jakarta, IIED, London, UK, 2014.

Chang, M. C., Shaeffer, S., Al-Samarrai, S., Ragatz, A. B., de Ree, J., and Stevenson, R.: Main Report - Teacher reform in Indonesia: the role of politics and evidence in policy making, World Bank Group, Washington DC, USA, 2013.

Desfandi, M.: Urgensi Kurikulum Pendidikan Kebencanaan Berbasis Kearifan Lokal di Indonesia, Sosio Didaktika, Vol. 1, 2014.

Dickson, E., Baker, J. L., Hoornweg, D., and Tiwari, A.: Urban development series - Urban risk assessments : understanding disaster and climate risk in cities, World Bank, Washington DC, USA, 2012.

Dicky, M., Haerani, E., Shibayama, M., Ueshima, M., Kagawa, N., and Hirnawan, F.: Disaster Awareness Education for Children in Schools Around Geological Hazard Prone Areas in Indonesia, Engineering Geology for Society and Territory, 6, 107-111, 2015.

Education Cluster: Education Needs Assessment Report on Jakarta Flood, 16-27 January 2013, Education Cluster, Jakarta, Indonesia, 2013.

GADRRRES and UNISDR: Comprehensive School Safety - A global framework in support of The Global Alliance for Disaster Risk Reduction and Resilience in the Education Sector and The Worldwide Initiative for Safe Schools, in preparation for the 3rd U.N. World Conference on Disaster Risk Reduction, 2015, GADDRESS \& UNISDR, 2014.

Government of Indonesia: Child Protection Law, Law no. 23 Year 2002, Government of Indonesia, Jakarta, Indonesia, 2002.

Hanushek, E. A. and Rivkin, S. G.: Does public school competition affect teacher quality?, in: The economics of school choice, edited by: Hoxby, C. M., University of Chicago Press, Chicago and London, 2003.

Haynes, K., Barclay, J., and Pidgeon, N.: Whose reality counts? Factors affecting the perception of volcanic risk, J. Volcanol. Geoth. Res., 172, 259-272, 2008.

Haynes, K., Coates, L., Leigh, R., Handmer, J., Whittaker, J., Gissing, A., McAneney, J., and Opper, S.: "Shelter-in-place" vs. evacuation in flash floods, Environmental Hazards, 8, 291-303, 2009.

Haynes, K. and Tanner, T. M.: Empowering young people and strengthening resilience: youth-centred participatory video as a tool for climate change adaptation and disaster risk reduction, Children's Geographies, 13, 357-371, 2015.

IFRC: Public awareness and public education for disaster risk reduction: key message, IFRC, Geneva, Switzerland, 2013.

Indonesian Red Cross: Sekolahku Aman, Bersih, dan Sehat, Indonesian Red Cross, Jakarta, Indonesia, 2009.

Johnson, V. A. and Ronan, K. R.: Classroom responses of New Zealand school teachers following the 2011 Christchurch earthquake, Nat. Hazards, 72, 1075-1092, 2014. 
Johnson, V. A., Ronan, K. R., Johnston, D. M., and Peace, R.: Implementing disaster preparedness education in New Zealand primary schools, Disaster Prevention and Management, 23, 370380, 2014.

King, D.: You're on Your Own: Community Vulnerability and the Need for Awareness and Education for Predicatable Natural Disasters, Journal of Contingencies and Crisis Management, 8, 223 228, 2000.

Kitzinger, J.: Qualitative Research: Introducing focus groups, BMJ, 311, 299-302, 1995.

Krueger, R. A. and Casey, M. A.: Participants in a Focus Group, in: Focus Groups A Practical Guide for Applied Research, edited by: Krueger, R. A. and Casey, M. A., Sage Publications, Inc, USA, 2015.

Masten, A. S., Narayan, A. J., Silverman, W. K., and Osofsky, J. D.: Children in War and Disaster, in: Handbook of Child Psychology and Developmental Science, edited by: Lerner, R. M., 4, John Wiley \& Sons, Inc., New Jersey, USA, 2015.

Ministry of Education and Culture: Indonesia Educational Statistics in Brief 2011/2012, Ministry of Education and Culture, Jakarta, Indonesia, 2012.

Ministry of Education and Culture: Roadmap Sekolah/Madrasah Sekolah Aman, Ministry of Education and Culture, Jakarta, Indonesia, 2015.

Ministry of Education of Indonesia: Pengarusutamaan Pengurangan Risiko Bencana di Sekolah, Surat Edaran Menteri No. 70A/MPN/SE/2010, Indonesia, 2010.

Mitchell, T., Haynes, K., Hall, N., Choong, W., and Oven, K.: The roles of children and youth in communicating disaster risk, Children Youth and Environments, 18, 254-279, 2008.

Molina, G., Molina, F., and Tanner, T.: Child-friendly participatory research tools, in: Community-based adaptation to climate change, edited by: Reid, H., Cannon, T., Berger, R., Alam, M., and Milligan, A., Participatory Learning and Action, 60, IIED, Nottingham, UK, 2009.

Morgan, D. L.: Focus Groups and Social Interaction, in: The SAGE Handbook of Interview Research: The Complexity of the Craft, edited by: Gubrium, J. F., Holstein, J. A., Marvasti, A. B., and McKinney, K. D., SAGE Publications, Inc., California, USA, 2012.

Moser, S.: Educating the nation: shaping student-citizens in Indonesian schools, Children's Geographies, 14, 247-262, doi:10.1080/14733285.2015.1033614, 2015.

Newman, E., Pfefferbaum, B., Kirlic, N., Tett, R., Nelson, S., and Liles, B.: Meta-Analytic Review of Psychological Interventions for Children Survivors of Natural and Man-Made Disasters, Curr. Psychiatry Rep., 16, 1-10, 2014.

Norris, F. H., Friedman, M. J., Watson, P. J., Byrne, C. M., Diaz, E., and Kaniasty, K.: 60,000 disaster victims speak: Part I. An empirical review of the empirical literature, 1981-2001, Psychiatry, 65, 207-239, 2002.

OECD/Asian Development Bank: Education in Indonesia: Rising to the challenge, OECD Publishing, Paris, 2015.

Paton, D., Smith, L., Daly, M., and Johnston, D. M.: Risk perception and volcanic hazard mitigation: Individual and social perspectives, J. Volcanol. Geoth. Res., 172, 179-188, 2008.

Peek, L.: Children and disasters: Understanding vulnerability, developing capacities, and promoting resilience-an introduction, Children Youth and Environments, 18, 1-29, 2008.
Petal, M. and Sanduvac, Z. T.: DREAMS for Turkey: A Case Study of Scale and Reach of Distance-Learning Self-Study for Individual and Household Preparedness and School Disaster Management, RiskRED, Turkey, 2012.

Plan International: Child-Centred DRR Toolkit, Woking, UK, Plan International, availabale at: https://plan-international.org/ file/625/download?token=8nS6wStN (last access: 7 April 2017), 2010.

Pusat Kurikulum: Modul Pelatihan Pengintegrasian Pengurangan Risiko Bencana ke dalam Sistem Pendidikan: Jenjang Pendidikan Dasar dan Menengah, SCDRR - UNDP, Jakarta, Indonesia, 2009.

Radar Surabaya: Gresik Raih Juara I Lomba UKS Tingkat Nasional, in: Radar Surabaya, Surabaya, Indonesia, 2016.

Ronan, K. R.: Advances and Continuing Challenges towards HFA2 and Post-2015: Background Chapter, UNESCO and UNICEF, Paris, France, Geneva, Switzerland, 2014.

Ronan, K. R. and Johnston, D. M.: Hazards Education for Youth: A Quasi-Experimental Investigation, Risk Anal., 23, 1009-1020, 2003.

Ronan, K. R., Johnston, D. M., Daly, M., and Fairley, R.: School children's risk perceptions and preparedness: A hazards education survey, Australasian Journal of Disaster and Trauma Studies, 1, 2001-2001, 2001.

Ronan, K. R., Crellin, K., and Johnston, D. M.: Correlates of hazards education for youth: a replication study, Nat. Hazards, 53, 503-526, 2010.

Sagala, S., Lassa, J., Yasaditama, H., and Hudalah, D.: The evolution of risk and vulnerability in Greater Jakarta: contesting government policy, Institute for Resource Governance and Social Change, Kupang, Indonesia, 2013.

Save the Children: Advocacy Matters: Helping children change their world - Participants Manual, The International Save the Children Alliance, London, UK, 2007a.

Save the Children: Pedoman Pelatihan: Pengurangan Risiko Bencana yang Dimotori oleh Anak-anak di Sekolah dan Komunitas, Save the Children, Bangkok, Thailand, 2007b.

Save the Children: Baseline Study Report - Disaster Risk Reduction "Pengurangan Risiko Bencana di Sekolah Terintegrasi" (DRR PRESTASI), Save the Children, Jakarta, 2014.

Sayer, R. A.: Method in social science: a realist approach, Routledge, London, UK, 1992.

Shimura, T. and Yamagata, K.: The Great East Japan Disaster and Geography Education: School Damage, Associations' Support Project, and Trends in Geography Teaching Practices, Geography Education in Japan, 3, 221-233, 2015.

Sopaheluwakan, J., Hidayati, D., Permana, H., Pribadi, K., Ismail, F., Meyers, K., Widayatun, Handayani, T., Bustami, D. A., Daliyo, Fitranita, Nagib, L., Ngadi, Kumoro, Y., Rafliana, I., and Argo, T.: Kajian Kesiapsiagaan Masyarakat Dalam Mengantisipasi Bencana Gempa Bumi \& Tsunami. LIPI - UNESCO/ISDR, Jakarta, Indonesia, 2006.

Swiss Re: Mind the risk - A global ranking of cities under threat from natural disasters, Swiss Re, Zurich, Switzerland, 2014.

Tadjoeddin, M. Z.: Anatomy of Social Violence in the Context of Transition: The Case of Indonesia 1990-2001, Politics, administration, and change, 38, p. 35, 2002. 
Tanner, T.: Shifting the Narrative: Child-led Responses to Climate Change and Disasters in El Salvador and the Philippines, Child. Soc., 24, 339-351, 2010.

Towers, B.: Children's knowledge of bushfire emergency response, Int. J. Wildland Fire, 24, 179-189, 2015.

Towers, B., Haynes, K., Sewell, F., Bailie, H., and Cross, D.: Childcentred disaster risk reduction in Australia: Progress, gaps and opportunities, Australian Journal of Emergency Management, 29, 31-38, 2014.

UNESCO: Stay safe and be prepared: A teacher's guide to disaster risk reduction, UNESCO, Paris, France, 2014.

UNESCO and UNICEF: Disaster risk reduction in school curricula: case studies from thirty countries, UNICEF \& UNESCO, Spain, 2012.

UNESCO and UNICEF: Towards a Learning Culture of Safety and Resilience: Technical guidance for integrating disaster risk reduction in the school curriculum, UNESCO, Paris, France, 2014.

UNICEF: The State of the World's Children 1996, Oxford University Press, New York, USA, 1996.

UNICEF: The state of the world's children 2014 in numbers: Every child counts, UNICEF, New York, USA, 2014.

UNISDR: Hyogo framework for action 2005-2015: building the resilience of nations and communities to disasters, UNISDR, Geneva, Switzerland, 2005.

UNISDR: Disaster Prevention for Schools: Guidance for Education Sector Decision-Makers, Consultation version, November 2008, UNISDR, Geneva, Switzerland, 2008.

UNISDR: Terminology on disaster risk reduction. UNISDR, Geneva, Switzerland, 2009.

UNISDR: Making Cities Resilient Report 2012, My city is getting ready!: A global snapshot of how local governments reduce disaster risk, 2012.

UNISDR: Commitments to Safe Schools: Summary Report, UNISDR, Geneva, Switzerland, 2015a.

UNISDR: Sendai Framework for Disaster Risk Reduction 20152030, UNISDR, 2015b.
United Nations: Convention on the Rights of the Child, United Nations, 1989.

United Nations: Yokohama Strategy and Plan of Action for a Safer World: guidelines for natural disaster prevention, preparedness and mitigation, United Nations, Yokohama, Japan, 1994.

Vernez, G., Karam, R., and Marshall, J.: Implementation of schoolbased management in Indonesia, World Bank, Jakarta, 2012.

Webb, M. and Ronan, K. R.: Interactive Hazards Education Program for Youth in a Low SES Community: A QuasiExperimental Pilot Study, Risk Anal., 34, 1882-1893, 2014.

Whittaker, J., Haynes, K., Handmer, J., and McLennan, J.: Community safety during the 2009 Australian 'Black Saturday' bushfires: an analysis of household preparedness and response, Int. J. Wildland Fire, 22, 841-849, 2013.

WHO: Communicable disease control in emergencies: A Field Manual, edited by: Connolly, M. A., ISBN-10: 92-4-154616-6, 301 pp., Geneva, Switzerland, 2005.

WHO: Child Health, in: Disaster Risk Management for Health Fact Sheets, WHO, 2011.

WHO: Hygiene promotion in emergencies, in: Technical Notes on Drinking-Water, Sanitation and Hygiene in Emergencies, edited by: Reed, B., WHO, Geneva, Switzerland, 2013.

Wisner, B.: Let our children teach us, A Review of the Role of Education and Knowledge in Disaster Risk Reduction, UNISDR System Thematic Cluster/Platform on Knowledge and Education, Geneva, Switzerland, 2006.

World Bank: Jakarta Urgent Flood Mitigation Project/Jakarta Emergency Dredging Initiative Project, World Bank, Jakarta, Indonesia, 2014a.

World Bank: World Bank and Education in Indonesia, World Bank, Jakarta, Indonesia, 2014b.

Wößmann, L.: International Evidence on School Competition, Autonomy, and Accountability: A Review, Peabody J. Educ., 82, 473-497, 2007. 